\title{
22. PRELIMINARY ORGANIC ANALYSES OF THE DEEP SEA DRILLING PROJECT CORES, LEG $10^{1}$
}

\author{
Bernd R. Simoneit, E. Sloan Scott, and A.L. Burlingame², Space Sciences Laboratory, University of California, \\ Berkeley, California
}

\begin{abstract}
The solvent soluble organic matter extracted from two core samples from DSDP Leg 10 was analyzed using GC and GC/MS techniques. The samples from Site 90 was of Early Miocene age and the extract consisted mainly of normal alkanes, $\mathrm{C}_{n} \mathrm{H}_{2 n+2}$, ranging from $n=14$ to $n=33$, with an odd over even predominance and maximum abundance above $\mathrm{C}_{24}$. Approximately eight per cent of the extract consisted of normal carboxylic acids, $\mathrm{C}_{n} \mathrm{H}_{2 n} \mathrm{O}_{2}$, ranging from $n=13$ to $n=31$, with an even over odd predominance and palmitic and lignorceric acids most abundant. The sample from Site 92 was of Late Pleistocene age and the extract consisted mainly of normal alkanes $\mathrm{C}_{n} \mathrm{H}_{2 n+2}$ with $n=$ 11 to $n=33$, with an odd over even predominance and maximum abundance above $\mathrm{C}_{24}$. Again, approximately 10 per cent of the extract consisted of normal carboxylic acids, $\mathrm{C}_{n} \mathrm{H}_{2 n} \mathrm{O}_{2}$, ranging from $n=13$ to $n=31$, with an even over odd predominance and lignoceric acid most abundant. In this sample, minor amounts of terpenoidal compounds were detected. Organic contamination was minor for both samples and consisted mainly of butyl esters from the core tubes. The bulk of the solvent soluble organic matter in these samples (especially Site 92) is of terrigenous origin, probably from turbidite runoff from the Mississippi Cone.
\end{abstract}

\section{INTRODUCTION}

Leg 10 of the Deep Sea Drilling Project was conducted in the Gulf of Mexico. Only two samples were received at this laboratory for analysis. The sample from Site 90 (1090-7-2, 40-140), drilled within the deep basin in a water depth of 3,713 meters, was recovered from 353 meters below the sea bed. It is of Early Miocene age (approximately $20 \times 10^{6}$ ) and consists mainly of silts with a low fossil content. The sample from Site 92 (10-92-5-4, 50150), drilled just above the Sigsbee Scarp in a water depth of 2,573 meters, was recovered from 178 meters below the sea bed. It is of Late Pleistocene age $\left(<10^{6}\right)$ and consists of gray silty clay.

\section{EXPERIMENTAL PROCEDURES}

Gas chromatographic (GC) analyses were carried out using a Perkin-Elmer Model 900 gas chromatograph fitted with a flame ionization detector and operating under the conditions stated in the respective figure legends. Analyses using gas chromatography-mass spectrometry were carried out on a modified Perkin-Elmer Model 270 GC/MS linked on-line to an XDS Sigma 2 computer (Smith et al., 1971). The GC conditions used in the GC/MS analyses are cited in the respective figure legends, and the mass

\footnotetext{
'Research supported by the Oceanographic Section, National Science Foundation NSF Grant GA-24214.

${ }^{2} J o h n$ Simon Guggenheim Memorial Fellow, 1970-1971.
}

spectrometric and computer operating parameters are as reported (Smith et al., 1971).

All solvents used, e.g., benzene, methanol, and $n$-heptane, were Mallinckrodt Nanograde quality. Benzene and methanol were redistilled prior to use.

The samples were extracted with benzene and methanol (3:1) in a Soxhlet apparatus for eight days. The heptane-diethyl ether soluble components of these extracts were divided into acidic and neutral fractions. The methods are essentially the same as discussed in earlier reports (Simoneit and Burlingame, $1971 \mathrm{a}$ and b; and 1972 a), where a flow diagram of this procedure is given.

\section{RESULTS}

The salient analytical results and yields for the samples are listed in Table 1 .

\section{Sample 10-90-7-2 (40-140)}

The GC trace of the heptane-ether soluble neutral fraction is given in Figure 1a and the GC/MS sum plots and individual scans are shown in Figure 2. The GC/MS results, listed in Table 2, indicate this mixture is composed predominantly of normal alkanes, $\mathrm{C}_{n} \mathrm{H}_{2 n+2}$, ranging from $n=16$ to $n=33$. In the GC data, the range is from C ${ }_{14} \mathrm{H}_{30}$ to $\mathrm{C}_{33} \mathrm{H}_{68}$. The higher weight alkanes, above $\mathrm{C}_{24}$ $\mathrm{H}_{50}$, are much more abundant than the lower weight alkanes. There is an odd over even predominance which is especially noticeable above $n$-tetracosane. In the mass spectra of normal alkanes, $\mathrm{m} / \mathrm{e} 57$ is the base peak. The sum plot of the m/e 57 ions (Figure $2 \mathrm{~b}$ ) contains most of 
TABLE 1

Salient Results, Samples 10-90-7-2 (40-140) and 10-92-5-4 (50-150)

\begin{tabular}{|c|c|c|c|c|}
\hline Sample & $\begin{array}{c}\text { Organic } \\
\text { Carbon }{ }^{\mathrm{a}} \\
(\%)\end{array}$ & $\begin{array}{l}\text { Heptane/ } \\
\text { Ether } \\
\text { Soluble }\end{array}$ & $\begin{array}{l}\text { Acid } \\
\text { Fraction } \\
(\%)\end{array}$ & $\begin{array}{l}\text { Neutral } \\
\text { Fraction } \\
\quad(\%)\end{array}$ \\
\hline $10-90-7-2(40-140)$ & $\begin{array}{l}0.5 \\
1.9\end{array}$ & $90 \mathrm{ppm}(0.009 \%)$ & 8.3 & 91.7 \\
\hline $10-92-5-4(50-150)$ & $\begin{array}{l}0.8 \\
2.2\end{array}$ & $300 \mathrm{ppm}(0.03 \%)$ & 10 & 90 \\
\hline
\end{tabular}

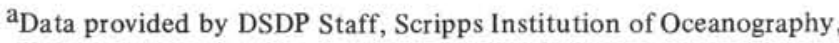
University of California at San Diego, and Chemistry Department, Woods Hole Oceanographic Institution.

the intense peaks found in the total ionization sum plot (Figure 2a). However, that plot has a much higher background level than the $\mathrm{m} / \mathrm{e} 57$ plot. This indicates that there are many compounds in the mixture which are not resolved on the gas chromatographic column. On the basis of the GC/MS data, the most abundant species in this extract is dibutyl azelate, $\mathrm{C}_{17} \mathrm{H}_{32} \mathrm{O}_{4}$. This and four other dibutyl esters found in the neutral fraction are contamination from the core tubes. These compounds were also detected in other DSDP core samples (Simoneit and Burlingame, 1972 a; Simoneit et al., 1972). Phthalate ester contamination is minor. One phthalate ester has been indentified in scan 117 by its base peak at m/e 149 which has the composition $\mathrm{C}_{8} \mathrm{H}_{5} \mathrm{O}_{3}$ (Structure 1).<smiles>O=C1[PH2+]C(=O)c2ccccc21</smiles>

I m/e $149, \mathrm{C}_{8} \mathrm{H}_{5} \mathrm{O}_{3}$

The most abundant ion in normal saturated acid ester mass spectra is $\mathrm{m} / \mathrm{e} 74$. The sum plot of the $\mathrm{m} / \mathrm{e} 74$ ions (Figure 2c) indicates only minor amounts of esters in the neutral fraction. The series, $\mathrm{C}_{n} \mathrm{H}_{2 n} \mathrm{O}_{2}$, ranges from $n=15$ to $n=31$, with $n=25$ most abundant. Methyl lignocerate $\left(\mathrm{C}_{25} \mathrm{H}_{30} \mathrm{O}_{2}\right)$ is also the most abundant species in the acid ester fraction of this core. The presence of methyl esters in the neutral fraction can probably be attributed to esterification of free fatty acids with methanol during Soxhlet extraction by catalysis of the slightly acidic clay content of the sediment.

The $\mathrm{m} / \mathrm{e} 191$ sum plot has no definite peaks above the background noise level which indicates that there are no terpenoidal components which exhibit a m/e 191 fragment ion in this mixture.

The GC trace of the acid fraction (as methyl esters) is shown in Figure $1 \mathrm{~b}$ and the GC/MS data of this fraction are shown in Figure 3. The GC/MS results, listed in Table 3 , indicate that this sample is mainly a series of saturated normal esters, $\mathrm{C}_{n} \mathrm{H}_{2 n} \mathrm{O}_{2}$. In the GC/MS data, the esters range from $n=13$ to $n=31$ and in the GC data the range

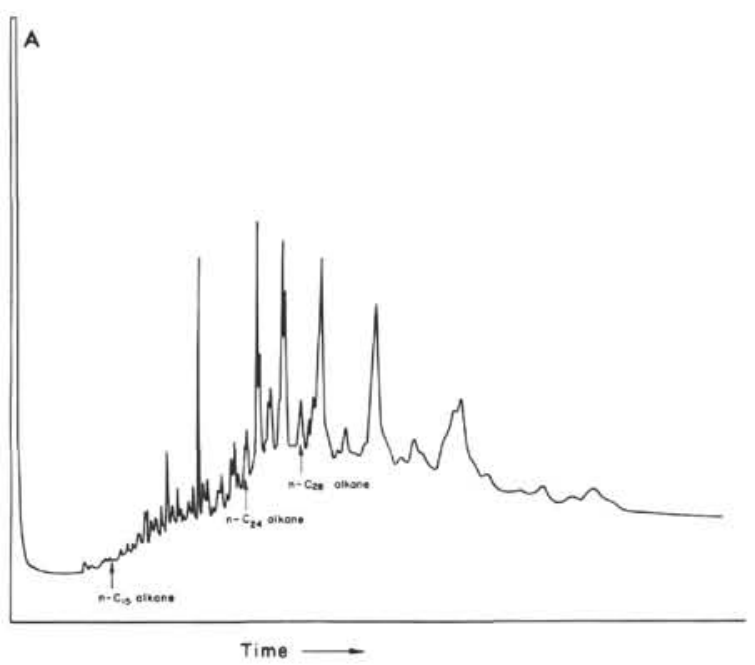

Figure 1a. Gas chromatogram of the heptane-ether soluble neutral extract from Sample 10-90-7-2(40-140). (Conditions: $10 \mathrm{ft}$. $\times 1 / 8 \mathrm{in}$. stainless steel column packed with $3 \%$ OV-1 on 100-200 mesh gaschrom Q, programmed from $100-275^{\circ} \mathrm{C}$ at $8^{\circ} / \mathrm{min}$ and using helium carrier gas at $60 \mathrm{ml} / \mathrm{min}$.) The arrows indicate the relative positions at which $\mathrm{n}$-pentadecane, $\mathrm{n}$-tetracosane and n-octacosane elute under the same chromatographic conditions.

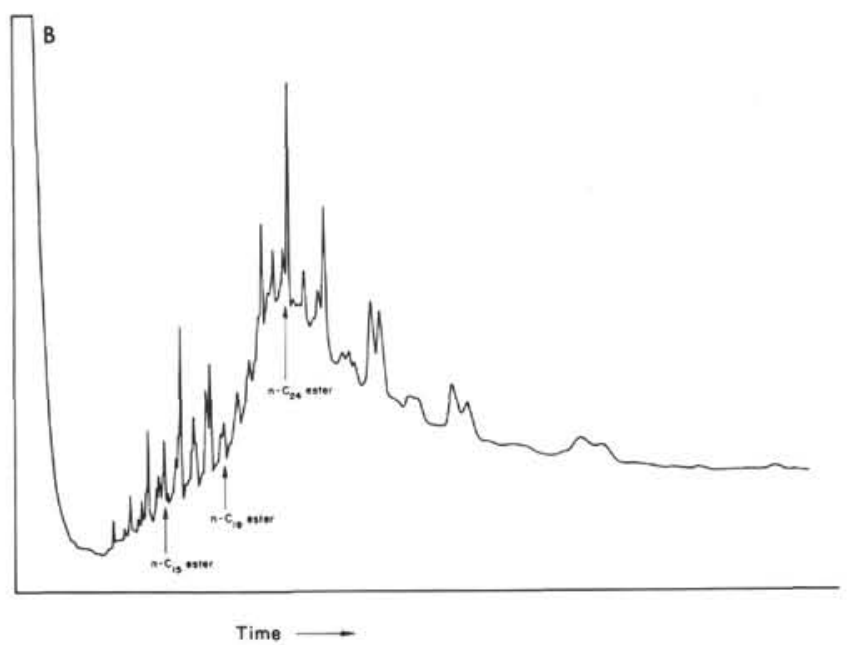

Figure 1b. Gas chromatogram of the heptane-ether soluble acid ester extract from Sample 10-90-7-2(40-140). (GC conditions as cited in Figure 1a.) The arrows indicate the relative positions at which methyl $\mathrm{n}$-pentadecanoate, methyl $\mathrm{n}$-heptadecanoate, and methyl lignocerate elute under the same chromatographic conditions.

is from $n=13$ to $n=33$. Methyl palmitate $\left(\mathrm{C}_{17} \mathrm{H}_{34}\right.$ $\left.\mathrm{O}_{2}\right)$ and methyl lignocerate $\left(\mathrm{C}_{25} \mathrm{H}_{50} \mathrm{O}_{2}\right)$ are the most abundant esters. The even-numbered acids predominate over the odd.

All the peaks found in the total sum plot are also found in the sum plot of the $\mathrm{m} / \mathrm{e} 74$ ions (McLafferty rearrangement). This indicates that all the resolved peaks are normal esters. Seven peaks in the m/e 74 sum plot (Figure 3d) are not normal esters. In the spectrum of each of these 
TABLE 2

Major Components of the Neutral Fraction from Sample 10-90-7-2 (40-140)

\begin{tabular}{|c|c|c|c|}
\hline $\begin{array}{c}\text { Spectrum at } \\
\text { Scan Number } \\
\text { (see } \\
\text { Figure 2a) }\end{array}$ & Compound Name & $\begin{array}{l}\text { Mol } \\
\text { and }\end{array}$ & $\begin{array}{l}\text { cular Weight } \\
\text { Composition }\end{array}$ \\
\hline 35 & biphenyl & 154 & $\mathrm{C}_{12} \mathrm{H}_{14}$ \\
\hline 72 & $n$-hexadecane & 226 & $\mathrm{C}_{16} \mathrm{H}_{34}$ \\
\hline 75 & dibutyl glutarate* & 244 & $\mathrm{C}_{13} \mathrm{H}_{24} \mathrm{O}_{4}$ \\
\hline 80 & branched alkane & 198 & \\
\hline 86 & $n$-heptadecane & 240 & $\mathrm{C}_{17} \mathrm{H}_{36}$ \\
\hline 92 & dibutyl adipate* & 258 & $\mathrm{C}_{14} \mathrm{H}_{26} \mathrm{O}_{4}$ \\
\hline 95 & unknown & 346 & \\
\hline 101 & $n$-octadecane & 254 & $\mathrm{C}_{18} \mathrm{H}_{38}$ \\
\hline 105 & unknown ketone & 240 & $\mathrm{C}_{16} \mathrm{H}_{32} \mathrm{O}$ \\
\hline 114 & n-nonadecane & 268 & $\mathrm{C}_{19} \mathrm{H}_{40}$ \\
\hline 117 & phthalate ester & & \\
\hline 120 & dibutyl suberate* & 286 & $\mathrm{C}_{16} \mathrm{H}_{30} \mathrm{O}_{4}$ \\
\hline 128 & $n$-eicosane & 282 & $\mathrm{C}_{20} \mathrm{H}_{42}$ \\
\hline 132 & dibutyl azelate* & 300 & $\mathrm{C}_{17} \mathrm{H}_{32} \mathrm{O}_{4}$ \\
\hline 140 & $n$-heneicosane & 296 & $\mathrm{C}_{21} \mathrm{H}_{44}$ \\
\hline 152 & $n$-docosane & 310 & $\mathrm{C}_{22} \mathrm{H}_{46}$ \\
\hline 155 & dibutyl hendecanedioate* & 328 & $\mathrm{C}_{19} \mathrm{H}_{36} \mathrm{O}_{4}$ \\
\hline 164 & $n$-tricosane & 324 & $\mathrm{C}_{23} \mathrm{H}_{48}$ \\
\hline 175 & $n$-tetracosane & 338 & $\mathrm{C}_{24} \mathrm{H}_{50}$ \\
\hline 186 & $n$-pentacosane & 352 & $\mathrm{C}_{25} \mathrm{H}_{52}$ \\
\hline 197 & $n$-hexacosane & 366 & $\mathrm{C}_{26} \mathrm{H}_{54}$ \\
\hline 211 & $n$-heptacosane & 380 & $\mathrm{C}_{27} \mathrm{H}_{56}$ \\
\hline 227 & n-octacosane & 394 & $\mathrm{C}_{28} \mathrm{H}_{58}$ \\
\hline 246 & $n$-nonacosane & 408 & $\mathrm{C}_{29} \mathrm{H}_{60}$ \\
\hline 270 & $n$-triacontane & 422 & $\mathrm{C}_{30} \mathrm{H}_{62}$ \\
\hline 304 & $n$-hentriacontane & 436 & $\mathrm{C}_{31} \mathrm{H}_{64}$ \\
\hline 345 & $n$-dotriacontane & 450 & $\mathrm{C}_{32} \mathrm{H}_{66}$ \\
\hline 396 & $n$-tritriacontane & 464 & $\mathrm{C}_{33} \mathrm{H}_{68}$ \\
\hline
\end{tabular}

*Core Tube Contamination

peaks, the $\mathrm{m} / \mathrm{e} 55$ ion (Figure $3 \mathrm{~b}$ ) is more intense than the $\mathrm{m} / \mathrm{e} 57$ ion (Figure 3c) indicating the esters may be unsaturated.

The m/e 191 sum plot has a low intensity for the most abundant peak compared to the intensity at the most abundant ester peak. The $\mathrm{m} / \mathrm{e} 191$ sum plot contains no distinct peaks above the background noise; therefore, there appear to be no terpenoidal compounds which form $\mathrm{m} / \mathrm{e} 191$ ions present in this mixture. Contamination from phthalate esters, as indicated by the $\mathrm{m} / \mathrm{e} 149$ sum plot, appear to be very small.

\section{Sample 10-92-5-4 (50-150)}

The GC trace of the neutral fraction is shown in Figure 4a. The GC/MS data of the neutral fraction are shown in Figures 5 and 6. The GC/MS results, listed in Table 4, indicate that the major components are normal alkanes, $\mathrm{C}_{n} \mathrm{H}_{2 n+2}$, ranging from $n=11$ to $n=31$ with $n$-heptacosane $\left(\mathrm{C}_{27} \mathrm{H}_{56}\right)$ and $n$-nonacosane $\left(\mathrm{C}_{29} \mathrm{H}_{60}\right)$ as the most abundant components. The GC data indicate a range from $n$ $=15$ to $n=33$. The odd-numbered alkanes are predominant over the even. For the major peaks, the m/e 57 sum plot intensities (Figure 5c) are generally three times greater than the m/e 55 sum plot intensities (Figure $5 b$ ), which indicates that the major peaks are all saturated hydrocarbons. There are two peaks (at scans 84 and 113) with $\mathrm{m} / \mathrm{e} 55$ peaks more intense than $\mathrm{m} / \mathrm{e} 57$ peaks. Scan 84 has a molecular ion at m/e 210 and an intense m/e 58 peak. It is possible laboratory contaminant, since it was found in another sample of this laboratory (Welch et al., unpublished results). Scan 113 fits the fragmentation pattern of dibutyl azelate, a core tube contaminant (Simoneit et al., 1972).

There does not appear to be any contamination from phthalate esters as indicated by the $\mathrm{m} / \mathrm{e} 149$ sum plot. A series of normal acid esters is indicated by the $\mathrm{m} / \mathrm{e} 74$ sum plot (figure 5d). From an intensity correlation of the data it can be concluded that the esters constitute approximately 1 per cent of the alkanes. The m/e 191 sum plot (Figure 5e) indicates a peak at scan 232. The scan 231 spectrum (Figure $6 \mathrm{~b}$ shows scan 232, a mixture) has a molecular ion at $\mathrm{m} / \mathrm{e} 384$, loss of a methyl radical to $\mathrm{m} / \mathrm{e}$ 369 , and a peak at $\mathrm{m} / \mathrm{e} 191$ (Structure II or III). The likely compositions for this compound

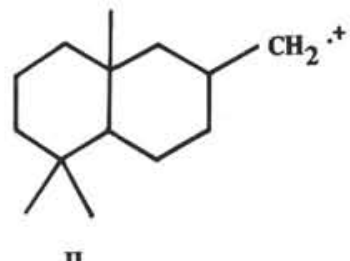

II

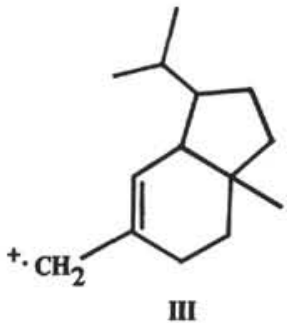

III

$$
\mathrm{m} / \mathrm{e} 191, \mathrm{C}_{14} \mathrm{H}_{23}
$$

are $\mathrm{C}_{28} \mathrm{H}_{48}$ (possible Structure IV) or $\mathrm{C}_{28} \mathrm{H}_{48}$ (a pentacyclic triterpane).

TABLE 3

Major Components of the Heptane-Ether Soluble Acid Ester Fraction From Sample 10-90-7-2 (40-140) as Determined by GC/MS and GC

\begin{tabular}{clll}
\hline $\begin{array}{c}\text { Spectrum at } \\
\text { Scan Number } \\
\text { (see }\end{array}$ & \multicolumn{1}{c}{ Compound Name } & $\begin{array}{c}\text { Molecular Weight } \\
\text { and Composition }\end{array}$ \\
\hline Figure 3a) & methyl laurate & 214 & $\mathrm{C}_{13} \mathrm{H}_{26} \mathrm{O}_{2}$ \\
54 & $\mathrm{C}_{14}$ methyl branched ester & 242 & $\mathrm{C}_{15} \mathrm{H}_{30} \mathrm{O}_{2}$ \\
70 & methyl myristate & 242 & $\mathrm{C}_{15} \mathrm{H}_{30} \mathrm{O}_{2}$ \\
85 & methyl pentadecanoate & 256 & $\mathrm{C}_{16} \mathrm{H}_{32} \mathrm{O}_{2}$ \\
100 & methyl palmitate & 270 & $\mathrm{C}_{17} \mathrm{H}_{34} \mathrm{O}_{2}$ \\
113 & octadecane & 254 & $\mathrm{C}_{18} \mathrm{H}_{38}$ \\
126 & methyl stearate & 298 & $\mathrm{C}_{19} \mathrm{H}_{38} \mathrm{O}_{2}$ \\
140 & methyl nonadecanoate & 312 & $\mathrm{C}_{20} \mathrm{H}_{40} \mathrm{O}_{2}$ \\
151 & methyl arachidate & 326 & $\mathrm{C}_{21} \mathrm{H}_{42} \mathrm{O}_{2}$ \\
163 & methyl heneicosanoate & 340 & $\mathrm{C}_{22} \mathrm{H}_{44} \mathrm{O}_{2}$ \\
173 & methyl behenate & 354 & $\mathrm{C}_{23} \mathrm{H}_{46} \mathrm{O}_{2}$ \\
186 & methyl tricosanoate & 368 & $\mathrm{C}_{24} \mathrm{H}_{48} \mathrm{O}_{2}$ \\
196 & methyl lignocerate & 382 & $\mathrm{C}_{25} \mathrm{H}_{50} \mathrm{O}_{2}$ \\
206 & methyl pentacosanoate & 396 & $\mathrm{C}_{26} \mathrm{H}_{32} \mathrm{O}_{2}$ \\
215 & methyl cerotate & 410 & $\mathrm{C}_{27} \mathrm{H}_{54} \mathrm{O}_{2}$ \\
225 & methyl octacosanoate & 438 & $\mathrm{C}_{29} \mathrm{H}_{58} \mathrm{O}_{2}$ \\
257 & methyl triacontanoate & 466 & $\mathrm{C}_{31} \mathrm{H}_{62} \mathrm{O}_{2}$ \\
270 & & & \\
& & & \\
\hline & & &
\end{tabular}




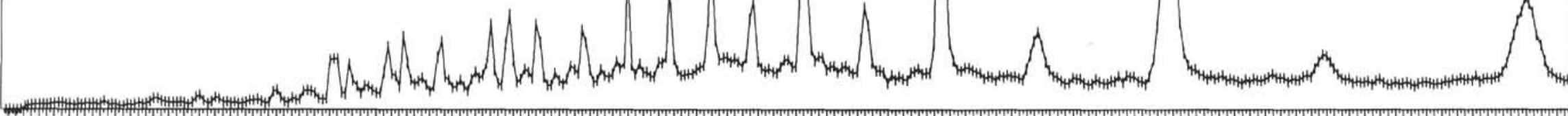

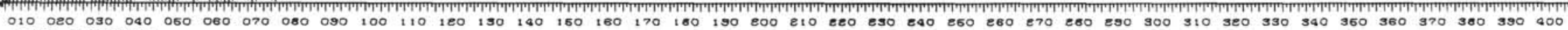

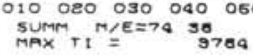

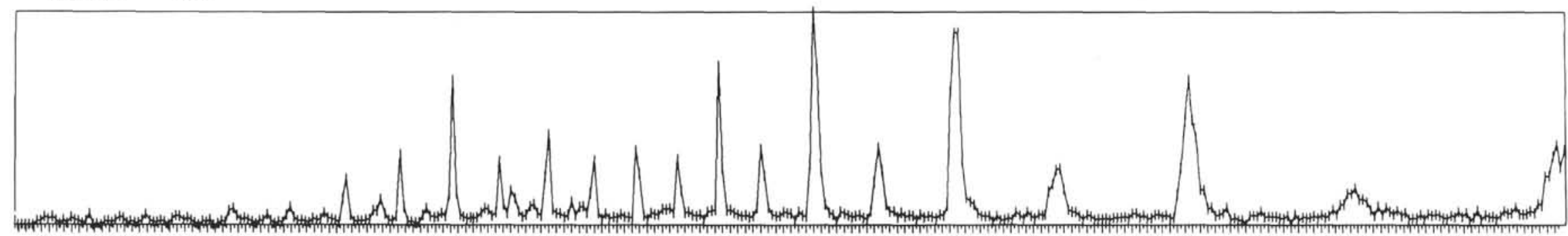

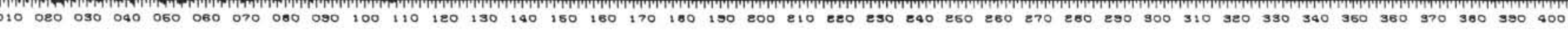
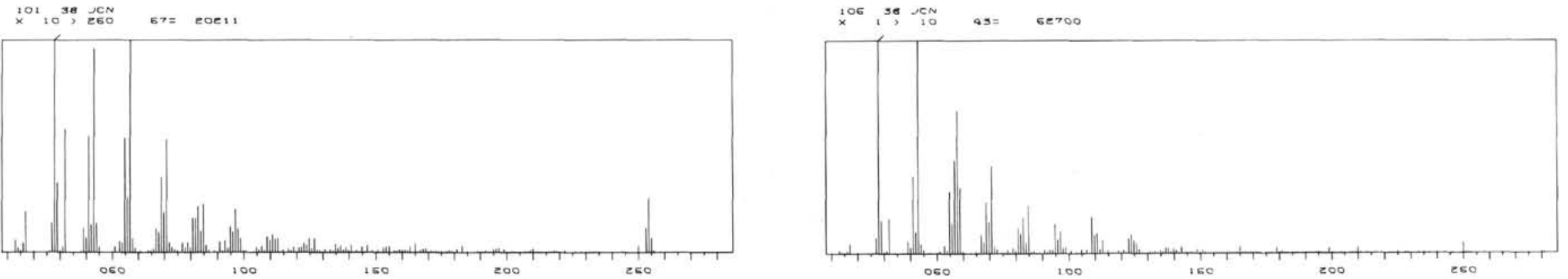

Figure 2. GC/MS data for the neutral fraction from Sample 10-90-7-2(40-140). (a) Total ionization sum plot; (b) m/e 57 sum plot; (c) $\mathrm{m} / \mathrm{e} 74$ sum plot; (d) Mass spectrum scan 101; (e) Mass spectrum scan 105. 
$\operatorname{sum}_{\sin }+{ }^{36}=\sec _{\text {siaqes }}$

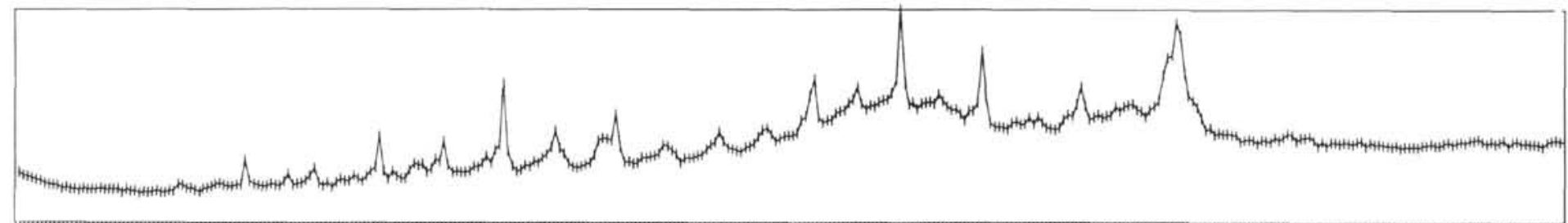

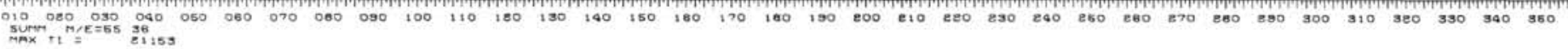

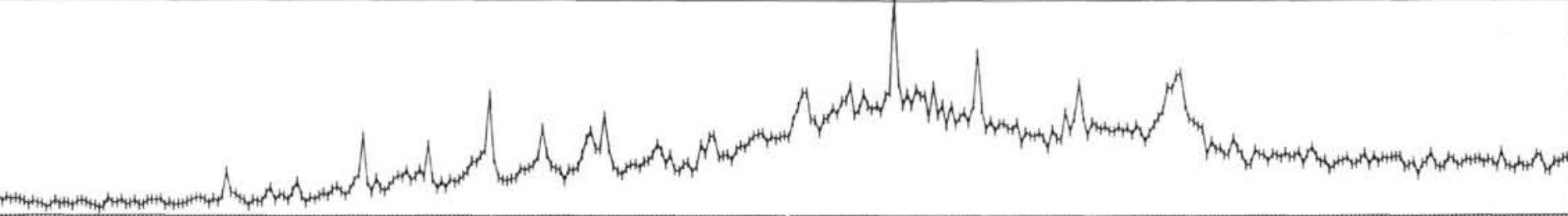

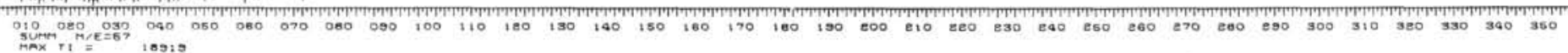

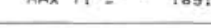

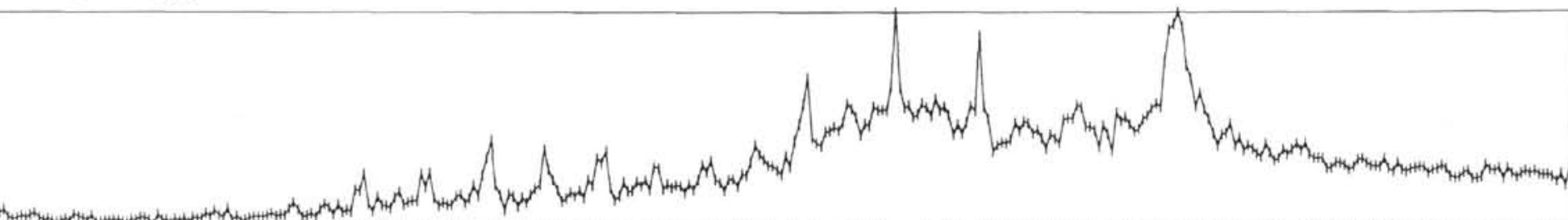

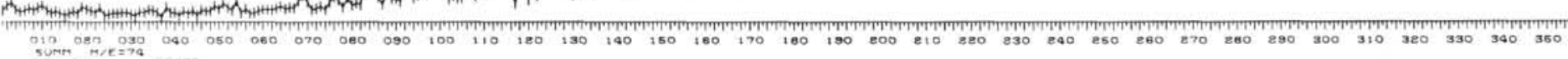

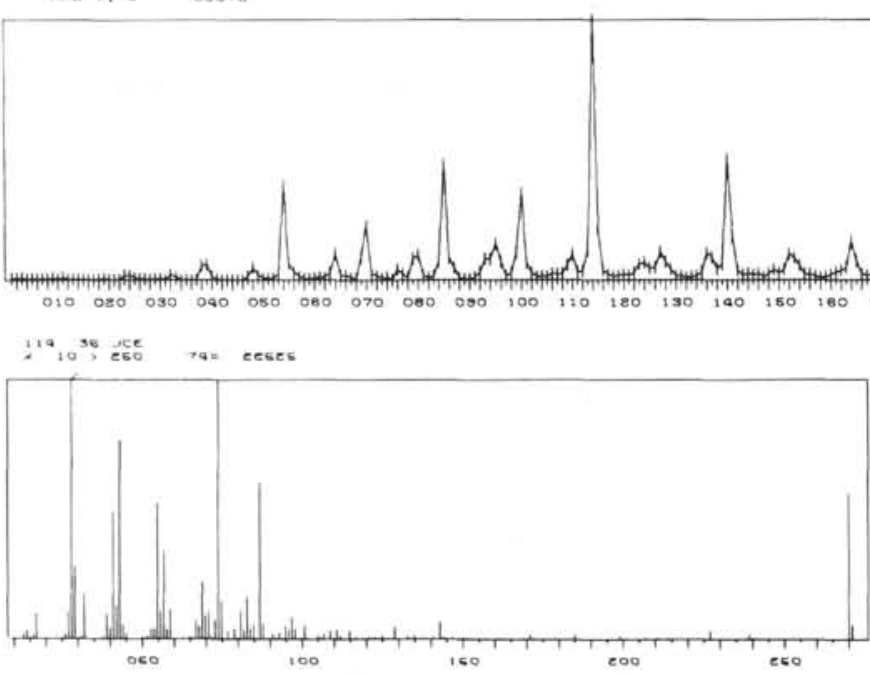

Figure 3. GC/MS data for the acid ester fraction from Sample 10-90-7-2(40-140). (a) Total ionization sum plot; (b) m/e 55 sum plot; (c) m/e 57 sum plot;(d) m/e 74 sum plot; (e) Mass spectrum scan 114 . 
<smiles>CC(C)CCCC(C)C1CCC2C3CCC4=CC(=O)CCC4(C)C3CCC12C</smiles>

IV $\mathrm{m} / \mathrm{e} 384, \mathrm{C}_{27} \mathrm{H}_{44} \mathrm{O}$

The scan 233 spectrum exhibits a molecular ion at $\mathrm{m} / \mathrm{e}$ 410 , loss of a methyl radical to $\mathrm{m} / \mathrm{e} 395$, and an intense $\mathrm{m} / \mathrm{e} 191$ peak (Structure II or III). There is also a minor peak at $\mathrm{m} / \mathrm{e} 426$, which could be an oxygenated species of the compound of molecular weight 410 . The likely composition for $\mathrm{m} / \mathrm{e} 410$ is $\mathrm{C}_{30} \mathrm{H}_{50}$ (e.g., possible Structure V). The m/e 77 sum plot exhibits<smiles>CC1(C)CCCC2(C)CCC3(C)C(CC=C4C5(C)CCCC(C)(C)C5CCC43C)C12</smiles>

$$
\mathrm{V} \mathrm{m} / \mathrm{e} 410, \mathrm{c}_{30} \mathrm{H}_{50}
$$

no distinct peaks above the background indicating this sample contains no aromatic compounds.

The GC trace of the acid fraction (as methyl esters) is shown in Figure $4 b$ and the GC/MS data appear in Figures 7 and 8 . The GC/MS results, listed in Table 5, indicate that the sample consists predominantly of a series of normal saturated methyl esters, $\mathrm{C}_{n} \mathrm{H}_{2 n} \mathrm{O}_{2}$. In the GC/MS data, the esters range from $n=13$ to $n=31$ and in the GC data the range is $n=15$ to $n=31$. Methyl lignocerate $\left(\mathrm{C}_{25} \mathrm{H}_{50} \mathrm{O}_{2}\right)$ is the most abundant ester. The even-numbered acids predominate over the odd. $\mathrm{C}_{15}$ and $\mathrm{C}_{17}$ methyl branched acid esters are found in scans 74 and 102 respectively. The mass spectra of the branched $\mathrm{C}_{15}$ acid ester and methyl n-pentadecanoate are shown in Figures $8 \mathrm{a}$ and $8 \mathrm{~b}$. Since there are no intense fragment ions at higher mass of scan 74, the branching is likely to be near the end of the chain, perhaps in the iso or anteiso position. The m/e 74 sum plot (Figure 7d) closely resembles the sum plot of the total ionization current (Figure 7e). All of the intense peaks coincide. However, in the higher molecular weight regions of the total ion sum plot (above methyl triacontanoate), a great deal more background, not present in the $\mathrm{m} / \mathrm{e} 74$ plot, is found.

A comparison of the intensities of the m/e 55 sum plot (Figure 7b) and the $\mathrm{m} / \mathrm{e} 57$ sum plot (Figure 7c) reveals a close similarity in the lower molecular weight range (below methyl triacontanoate) and more intense m/e 55 ions at higher molecular weights, indicating the presence
TABLE 4

Major Components of the Neutral Fraction From Sample 10-92-5-4 (50-150) as Determined by GC/MS and GC

\begin{tabular}{|c|c|c|c|}
\hline \multirow{2}{*}{$\begin{array}{c}\begin{array}{c}\text { Spectrum at } \\
\text { Scan Number } \\
\text { (see Figure 5a) }\end{array} \\
14\end{array}$} & \multirow{2}{*}{$\begin{array}{l}\text { Compound Name } \\
\text { n-undecane }\end{array}$} & \multicolumn{2}{|c|}{$\begin{array}{l}\text { Molecular Weight } \\
\text { and Composition }\end{array}$} \\
\hline & & 156 & $\mathrm{C}_{11} \mathrm{H}_{24}$ \\
\hline 31 & $n$-tridecane & 184 & $\mathrm{C}_{13} \mathrm{H}_{28}$ \\
\hline 48 & $n$-pentadecane & 212 & $\mathrm{C}_{15} \mathrm{H}_{32}$ \\
\hline 65 & $n$-heptadecane & 240 & $\mathrm{C}_{17} \mathrm{H}_{36}$ \\
\hline 80 & $n$-octadecane & 254 & $\mathrm{C}_{18} \mathrm{H}_{38}$ \\
\hline 84 & unknown* & 210 & $\mathrm{C}_{14} \mathrm{H}_{26} \mathrm{O}$ \\
\hline 94 & $n$-nonadecane & 268 & $\mathrm{C}_{19} \mathrm{H}_{40}$ \\
\hline 108 & $n$-eicosane & 282 & $\mathrm{C}_{20} \mathrm{H}_{42}$ \\
\hline 113 & dibutyl azelate $e^{\dagger}$ & 300 & $\mathrm{C}_{17} \mathrm{H}_{32} \mathrm{O}_{4}$ \\
\hline 120 & $n$-heneicosane & 296 & $\mathrm{C}_{21} \mathrm{H}_{44}$ \\
\hline 132 & $n$-docosane & 310 & $\mathrm{C}_{22} \mathrm{H}_{46}$ \\
\hline 144 & $n$-tricosane & 324 & $\mathrm{C}_{23} \mathrm{H}_{48}$ \\
\hline 156 & $n$-tetracosane & 338 & $\mathrm{C}_{24} \mathrm{H}_{50}$ \\
\hline 166 & $n$-pentacosane & 352 & $\mathrm{C}_{25} \mathrm{H}_{52}$ \\
\hline 176 & $n$-hexacosane & 366 & $\mathrm{C}_{26} \mathrm{H}_{54}$ \\
\hline 186 & $n$-heptacosane & 380 & $\mathrm{C}_{27} \mathrm{H}_{56}$ \\
\hline 196 & $n$-octacosane & 394 & $\mathrm{C}_{28} \mathrm{H}_{58}$ \\
\hline 205 & $n$-nonacosane & 408 & $\mathrm{C}_{29} \mathrm{H}_{60}$ \\
\hline 219 & $\begin{array}{l}\text { pentacyclic triterpane } \\
\text { unknown }\end{array}$ & 398 & $\mathrm{C}_{29} \mathrm{H}_{50}$ \\
\hline 229 & $n$-hentriacontane & 436 & $\mathrm{C}_{31} \mathrm{H}_{64}$ \\
\hline 231 & $\begin{array}{l}\text { pentacyclic triterpane } \\
\text { unknown }\end{array}$ & 384 & $\mathrm{C}_{28} \mathrm{H}_{48}$ \\
\hline 233 & $\begin{array}{l}\text { pentacyclic triterpane } \\
\text { unknown }\end{array}$ & 410 & $\mathrm{C}_{30} \mathrm{H}_{50}$ \\
\hline
\end{tabular}

*Possible laboratory contaminant

$\uparrow$ Core tube contamination

of unsaturated compounds in the higher mass regions which were not resolved by the gas chromatographic column. There appear to be no aromatic compounds in this mixture (m/e 77 sum plot at background levels) and contamination by phthalate esters (based on the m/e 149 sum plot) appears to be negligible.

There are a few distinct peaks in the $\mathrm{m} / \mathrm{e} 191$ sum plot (Figure 7e). The peaks at lower scan numbers are unresolved from the large ester peaks, but scans 371 and 432 are good spectra of terpenoidal compounds. The scan 371 spectrum exhibits a molecular ion at $\mathrm{m} / \mathrm{e} 468$ and fragment ions at $\mathrm{m} / \mathrm{e} 453,369,249,191,95$, and 81 as well as low intensity alkane fragmentation. The chemical separation technique for this fraction strongly suggests that these two compounds are triterpenoidal acids. A likely composition fitting for $\mathrm{m} / \mathrm{e} 468$ is $\mathrm{C}_{31} \mathrm{H}_{48} \mathrm{O}_{3}$ with the possible example Structures VI and VII. Structure VI is a compound related to oleanolic acid and Structure VII is an oxidized form derived from B-boswellic acid. The 


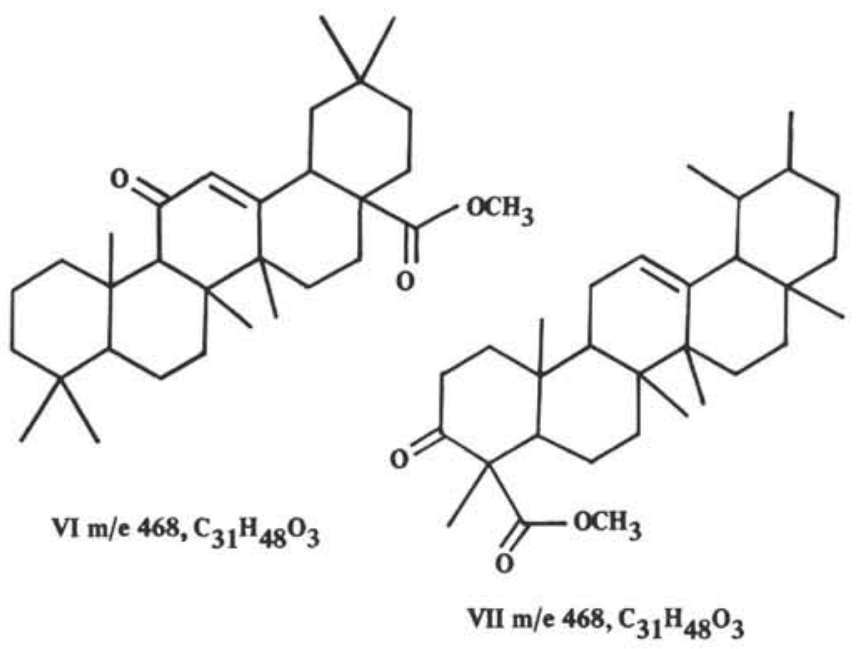

scan 432 spectrum (Figure 8d) exhibits a molecular ion at $\mathrm{m} / \mathrm{e} 484$, with loss of a methyl radical to $\mathrm{m} / \mathrm{e} 469$; fragment ions at $\mathrm{m} / \mathrm{e} 369,263,191,95$, and 81 ; and low intensity alkane fragmentation. A likely composition fitting for $\mathrm{m} / \mathrm{e} 484$ is $\mathrm{C}_{31} \mathrm{H}_{48} \mathrm{O}_{4}$ with the possible example Structure VIII, a compound related to glycyrrhetinic acid.
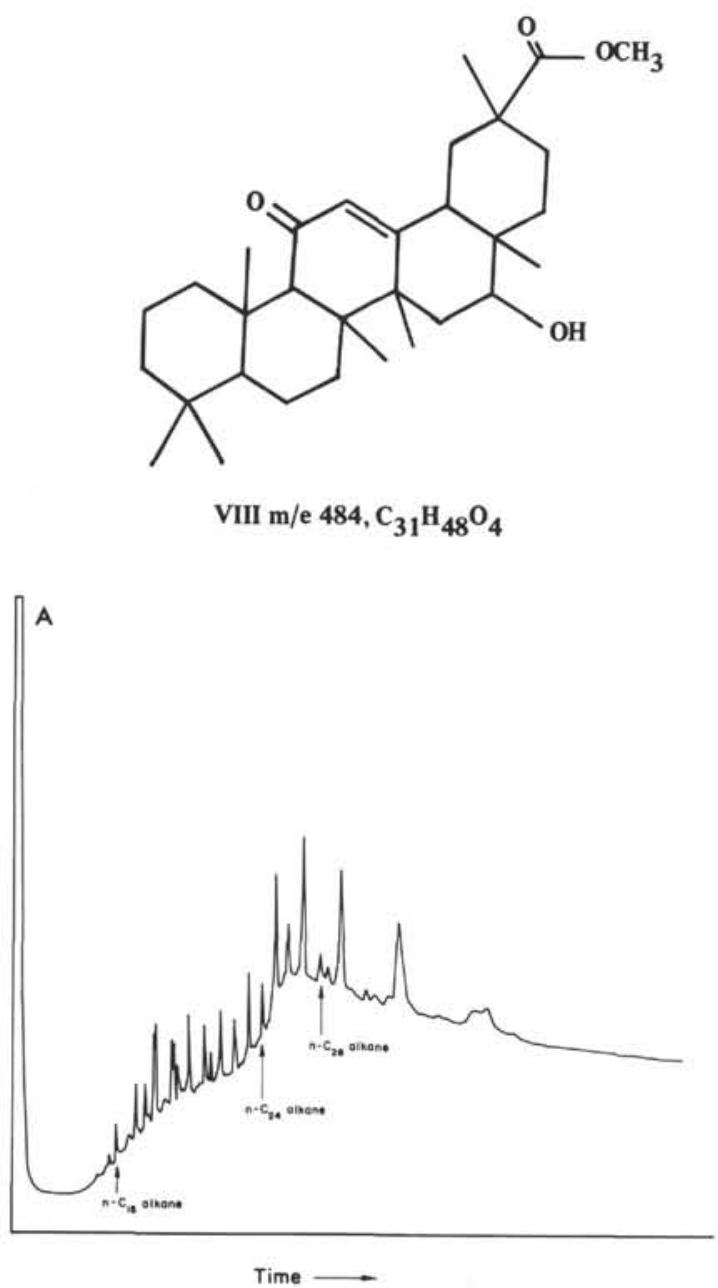

Figure 4a. Gas chromatogram of the heptane-ether soluble neutral extract from Sample 10-92-5-4(50-150). (Conditions as cited in Figure 1a.)

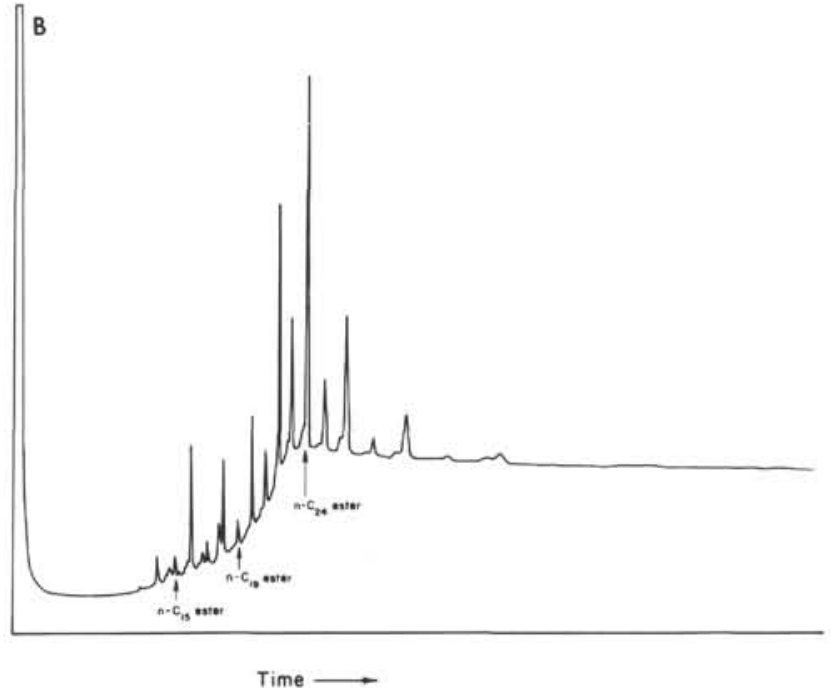

Figure 4b. Gas chromatogram of the heptane-ether soluble acid ester extract from Sample 10-92-5-4(50-150). (Conditions as cited in Figure 1a.)

TABLE 5

Major Components of the Heptane-Ether Soluble Acid Ester

Fraction from Sample 10-92-5-4 (50-150) as Determined by GC/MS and GC

\begin{tabular}{|c|c|c|c|c|}
\hline $\begin{array}{l}\text { Spectrum } \\
\text { at Scan } \\
\text { Number } \\
\text { (see } \\
\text { Figure 7a) }\end{array}$ & Compound Name & $\begin{array}{l}\text { Mole } \\
\text { and }\end{array}$ & $\begin{array}{l}\text { cular Weight } \\
\text { Composition }\end{array}$ & $\begin{array}{c}\text { Figure } \\
\text { Reference }\end{array}$ \\
\hline 34 & methyl laurate & 214 & $\mathrm{C}_{13} \mathrm{H}_{26} \mathrm{O}_{2}$ & - \\
\hline 49 & methyl tridecanoate & 228 & $\mathrm{C}_{14} \mathrm{H}_{28} \mathrm{O}_{2}$ & - \\
\hline 64 & methyl myristate & 242 & $\mathrm{C}_{15} \mathrm{H}_{30} \mathrm{O}_{2}$ & - \\
\hline 74 & $\begin{array}{l}\mathrm{C}_{15} \text { methyl branched } \\
\text { ester }\end{array}$ & 256 & $\mathrm{C}_{16} \mathrm{H}_{32} \mathrm{O}_{2}$ & $8 \mathrm{a}$ \\
\hline 78 & methyl pentadecanoate & 256 & $\mathrm{C}_{16} \mathrm{H}_{32} \mathrm{O}_{2}$ & $8 \mathrm{~b}$ \\
\hline 92 & methyl palmitate & 270 & $\mathrm{C}_{17} \mathrm{H}_{34} \mathrm{O}_{2}$ & - \\
\hline 102 & $\begin{array}{l}\mathrm{C}_{17} \text { methyl branched } \\
\text { ester }\end{array}$ & 284 & $\mathrm{C}_{18} \mathrm{H}_{36} \mathrm{O}_{2}$ & - \\
\hline 106 & methyl margarate & 284 & $\mathrm{C}_{18} \mathrm{H}_{36} \mathrm{O}_{2}$ & - \\
\hline 118 & methyl stearate & 298 & $\mathrm{C}_{19} \mathrm{H}_{38} \mathrm{O}_{2}$ & - \\
\hline 130 & methyl nonadecanoate & 312 & $\mathrm{C}_{20} \mathrm{H}_{40} \mathrm{O}_{2}$ & - \\
\hline 142 & methyl arachidate & 326 & $\mathrm{C}_{21} \mathrm{H}_{42} \mathrm{O}_{2}$ & - \\
\hline 153 & methyl heneicosanoate & 340 & $\mathrm{C}_{22} \mathrm{H}_{44} \mathrm{O}_{2}$ & - \\
\hline 163 & methyl behenate & 354 & $\mathrm{C}_{23} \mathrm{H}_{46} \mathrm{O}_{2}$ & - \\
\hline 173 & methyl tricosanoate & 368 & $\mathrm{C}_{24} \mathrm{H}_{48} \mathrm{O}_{2}$ & - \\
\hline 182 & methyl lignocerate & 382 & $\mathrm{C}_{25} \mathrm{H}_{50} \mathrm{O}_{2}$ & - \\
\hline 191 & methyl pentacosanoate & 396 & $\mathrm{C}_{26} \mathrm{H}_{52} \mathrm{O}_{2}$ & - \\
\hline 199 & methyl cerotate & 410 & $\mathrm{C}_{27} \mathrm{H}_{54} \mathrm{O}_{2}$ & - \\
\hline 210 & methyl heptacosanoate & 424 & $\mathrm{C}_{28} \mathrm{H}_{56} \mathrm{O}_{2}$ & - \\
\hline 223 & methyl octacosanoate & 438 & $\mathrm{C}_{29} \mathrm{H}_{58} \mathrm{O}_{2}$ & $8 \mathrm{c}$ \\
\hline 239 & methyl nonacosanoate & 452 & $\mathrm{C}_{30} \mathrm{H}_{60} \mathrm{O}_{2}$ & - \\
\hline 259 & methyl triacontanoate & 466 & $\mathrm{C}_{31} \mathrm{H}_{62} \mathrm{O}_{2}$ & - \\
\hline 371 & $\begin{array}{l}\text { pentacyclic triterpane } \\
\text { acid unknown }\end{array}$ & 468 & $\mathrm{C}_{31} \mathrm{H}_{48} \mathrm{O}_{3}$ & - \\
\hline 432 & $\begin{array}{l}\text { pentacyclic triterpane } \\
\text { acid unknown }\end{array}$ & 484 & $\mathrm{C}_{31} \mathrm{H}_{48} \mathrm{O}_{4}$ & $8 d$ \\
\hline
\end{tabular}




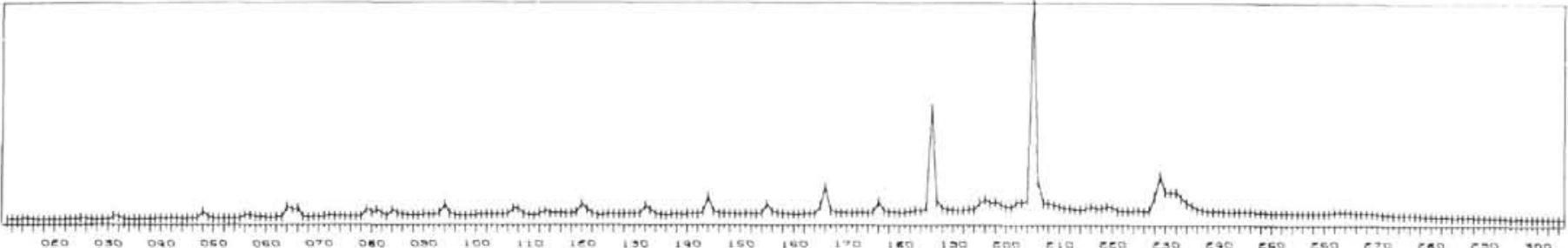

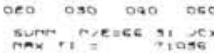

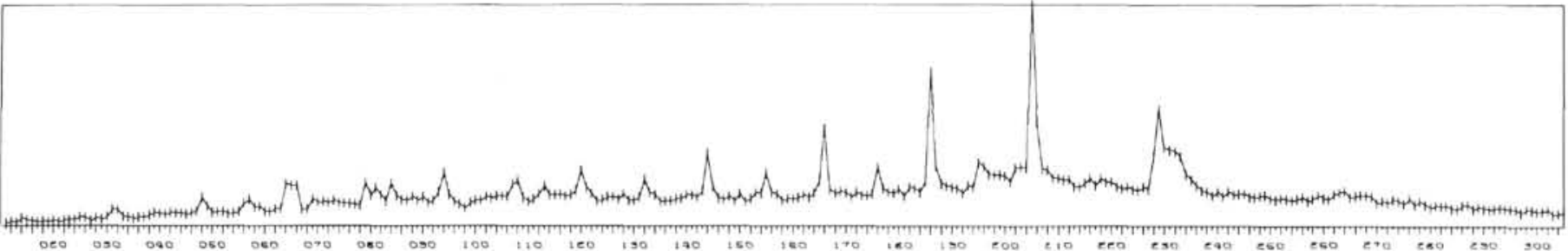

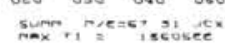

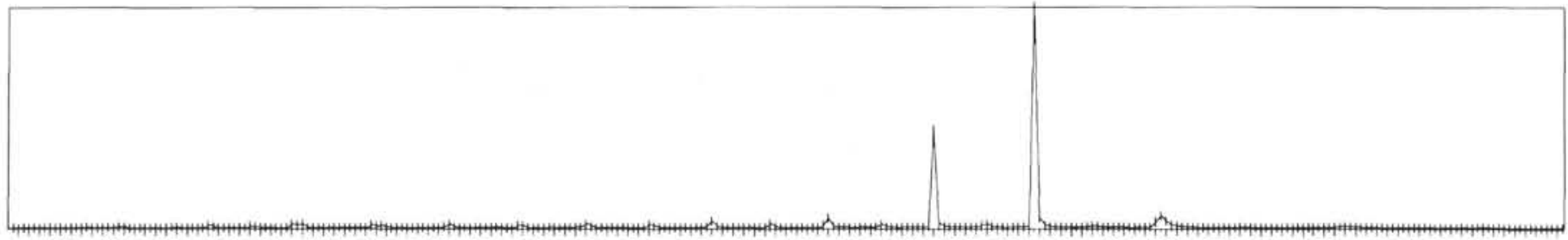

260

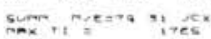

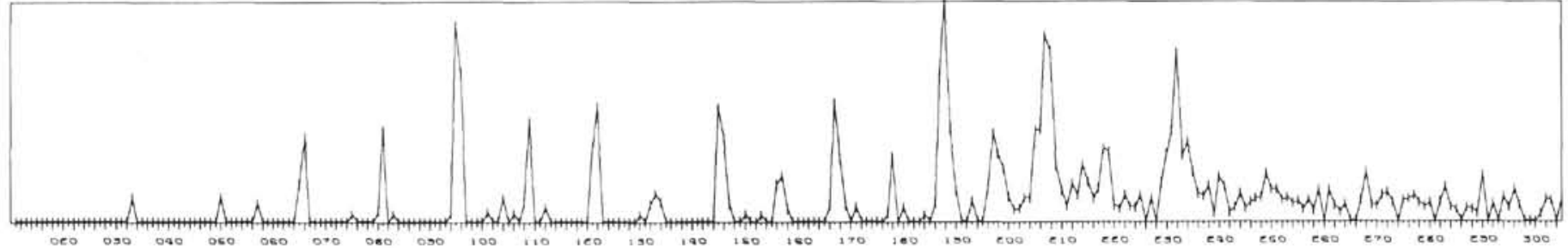

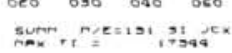

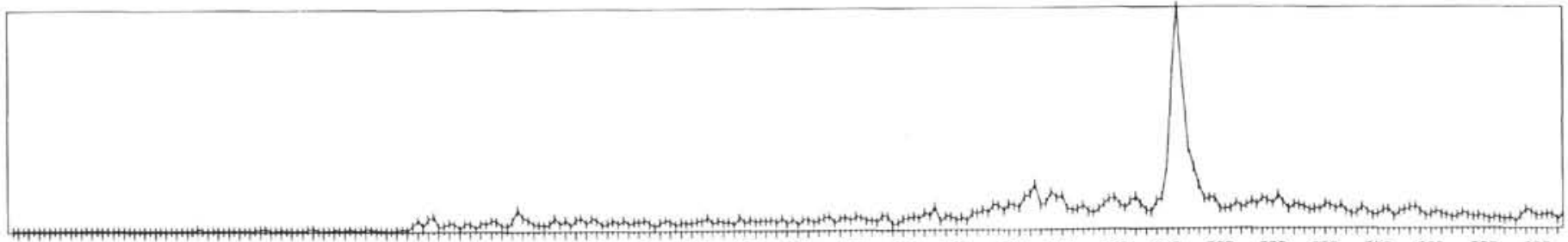

Figure 5. GC/MS data of the neutral fraction from Sample 10-92-5-4(50-150). (a) Total ionization sum plot; (b)/6e 55 sum plot; (c) m/e 57 sum plot;(d) m/e 74 sum plot; (e) m/e 191 sum plot. 


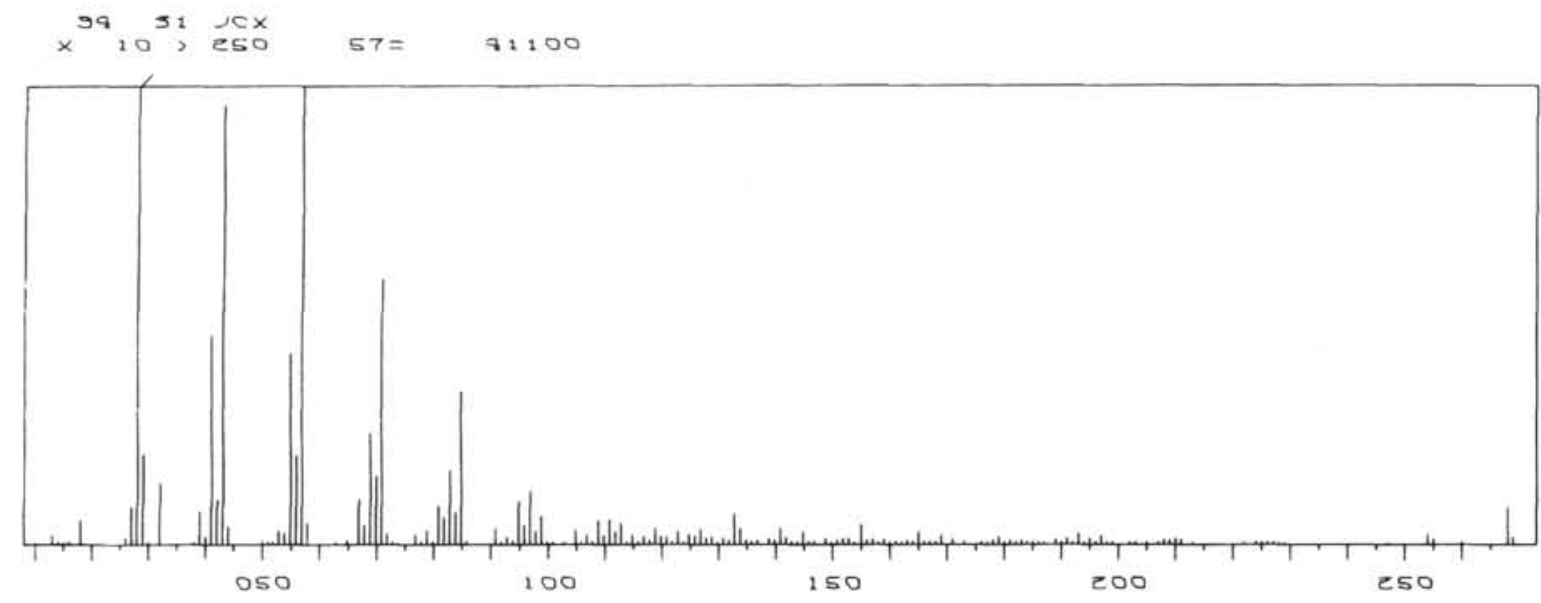

ese 51 fex
$x$

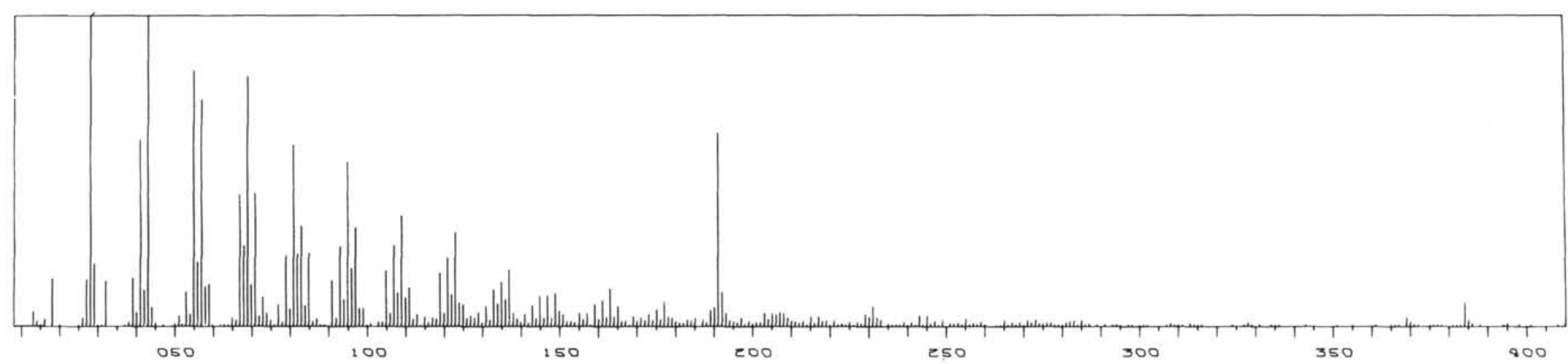

Figure 6. GC/MS data of the neutral fraction from Sample 10-92-5-4(50-150). (a) Mass spectrum scan 94; (b) Mass spectrum scan 232. 

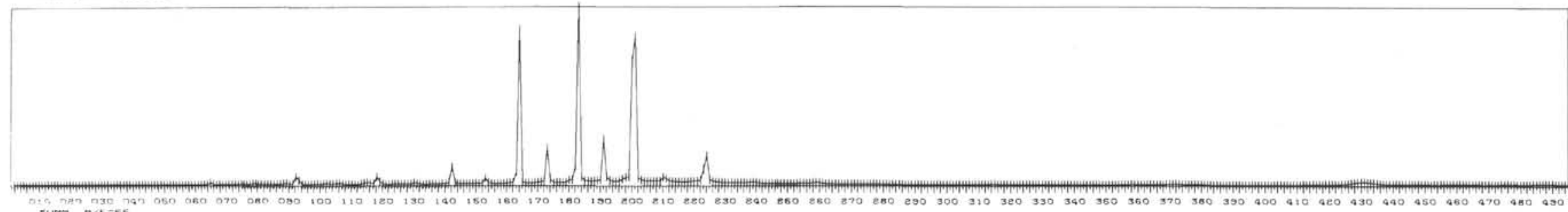

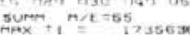

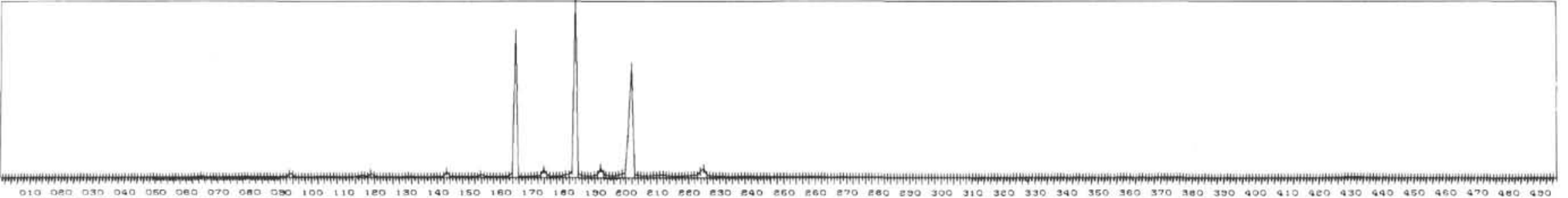

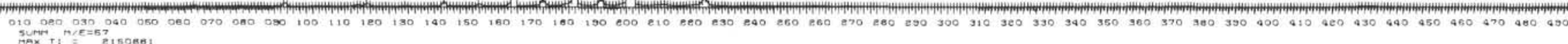
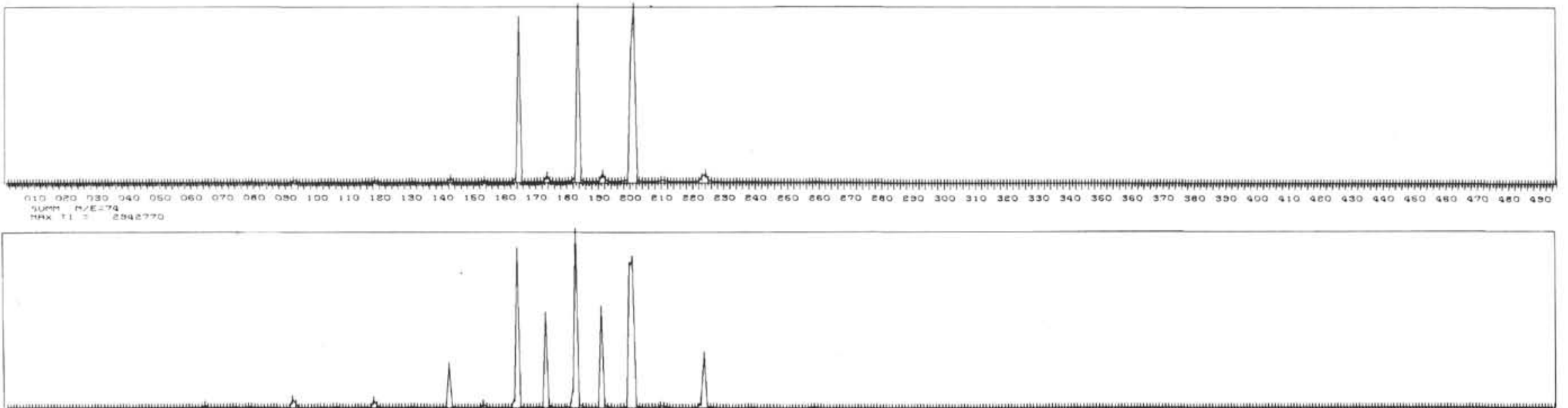

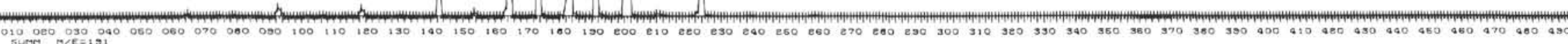

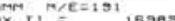

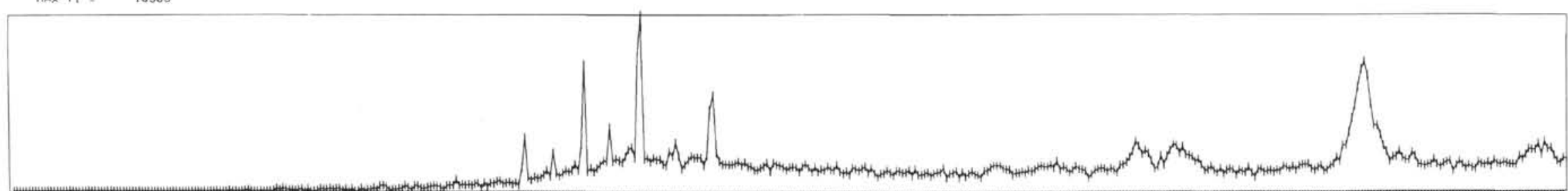

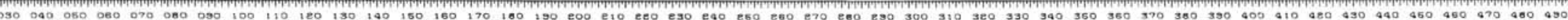

Figure 7. GC/MS data for the acid ester fraction from Sample 10-92-5-4(50-150). (a) Total ionization sum plot; (b) m/e 55 sum plot; (c) m/e 57 sum plot; (d) $m / e$ 74 sum plot; (e) m/e 191 sum plot. 

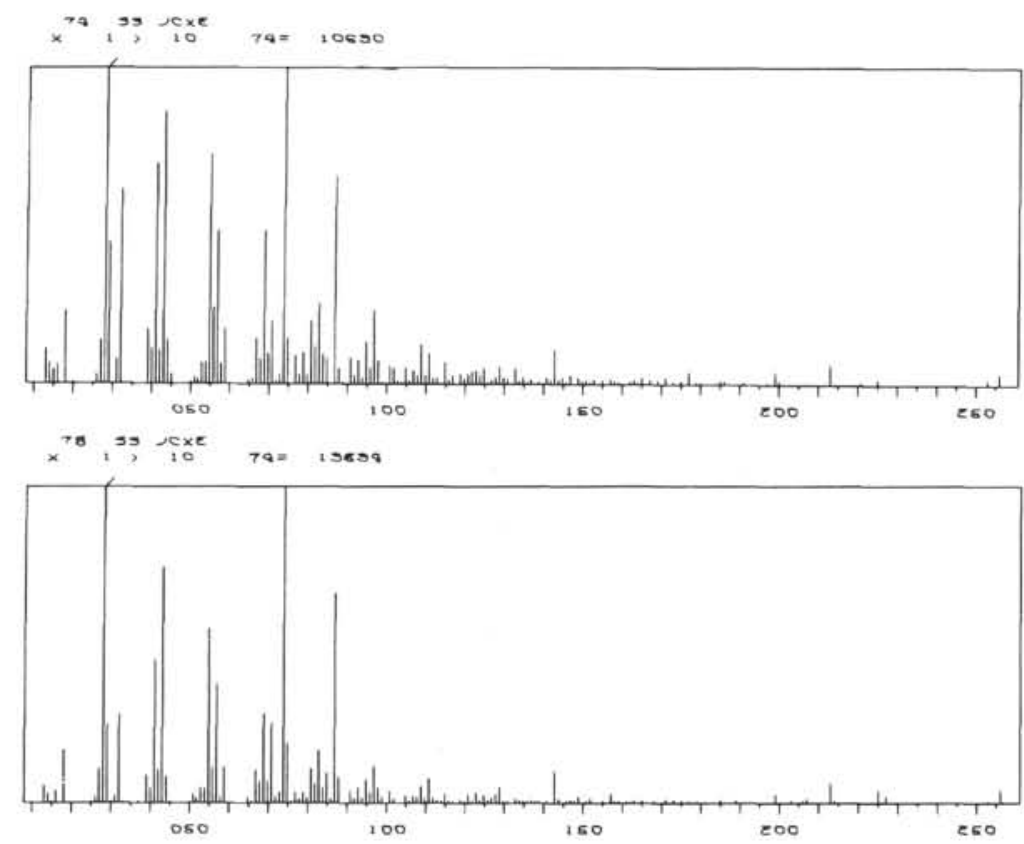

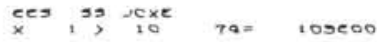

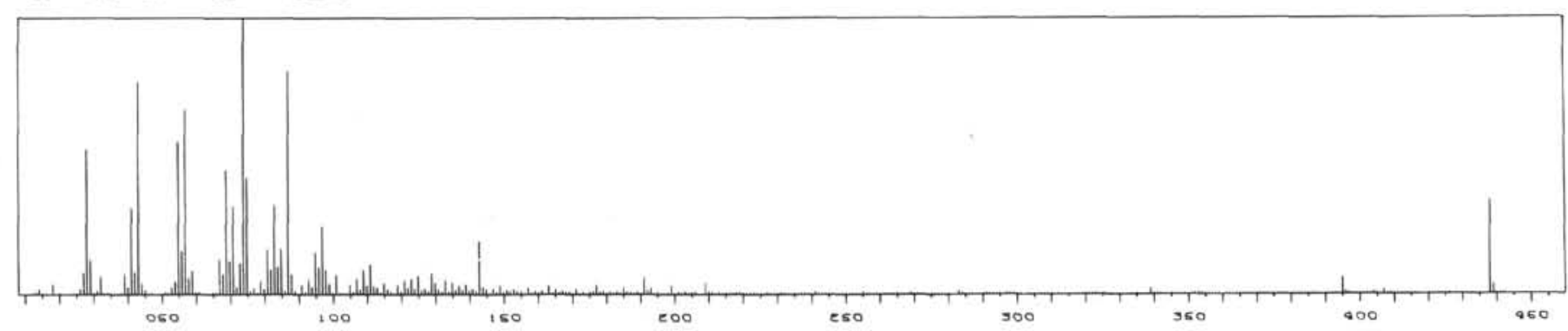

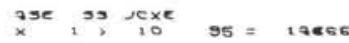

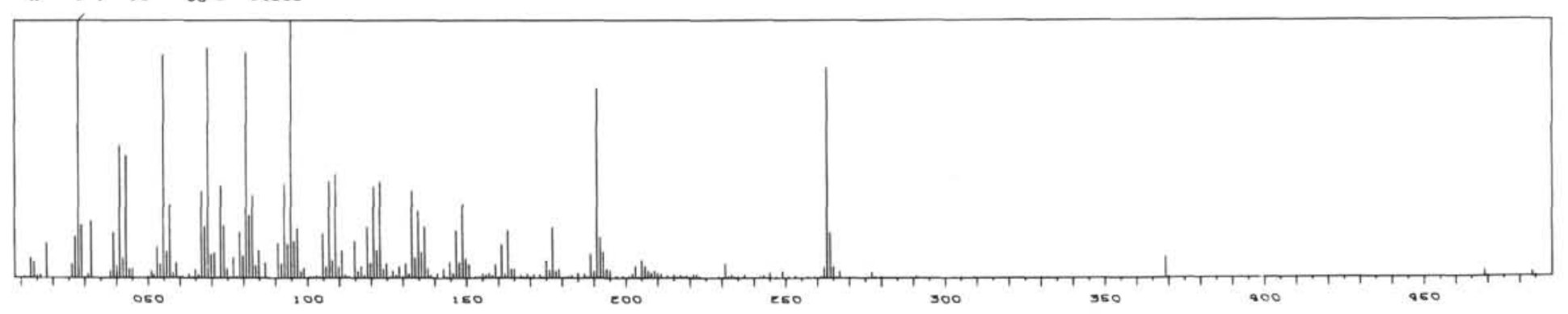

Figure 8. GC/MS data for the acid ester fraction from Sample 10-92-5-4(50-150). (a) Mass spectrum scan 74; (b) Mass spectrum scan 78; (c) Mass spectrum scan 223; (d) Mass spectrum scan 432. 


\section{CONCLUSIONS}

The solvent soluble organic matter from both samples consists of significant amounts of nonmarine derived components. The Pleistocene sample (Site 92) was drilled just above the Sigsbee Scarp, near the Mississippi Cone, and contains mainly clay minerals. The alkane and acid distribution histogram for this sample is shown in Figure 9b. It clearly indicates the strong odd to even predominance of the normal alkanes with the maximum concentration in the $\mathrm{C}_{25}$ to $\mathrm{C}_{33}$ range and the even to odd predominance of the normal carboxylic acids with the maximum concentration in the $\mathrm{C}_{24}$ range. Such a distribution pattern in the long carbon chain range is characteristic of terrestrial plant wax residues. These patterns (cf. Figure $9 b$ ) and the presence of terpenoidal compounds strongly indicate a terrigenous source for this soluble organic matter, probably from turbidites and particulate organic matter carried down the Mississippi River system (Simoneit and Burlingame, 1972b).

The Miocene sample (Site 90) from the deep basin also had a clay mineralogy and an abundance of methane gas was encountered. It exhibits a normal alkane distribution with a strong odd to even predominance, maximizing in the range of $\mathrm{C}_{25}-\mathrm{C}_{33}$ (cf. Figure 9a) and the normal carboxylic acid distribution has an even to odd predominance with maxima at $\mathrm{C}_{16}$ and $\mathrm{C}_{24}$ (cf. Figure 9a). Terpenoidal compounds were however not detected. The general compound distribution is analogous to Sample 10-92-5-4 as well as to samples analyzed from the Black Sea (Simoneit, in press) and it appears that the Gulf of Mexico may have had significant nonmarine influx during the Miocene. The total extractable organic matter from this sample is about
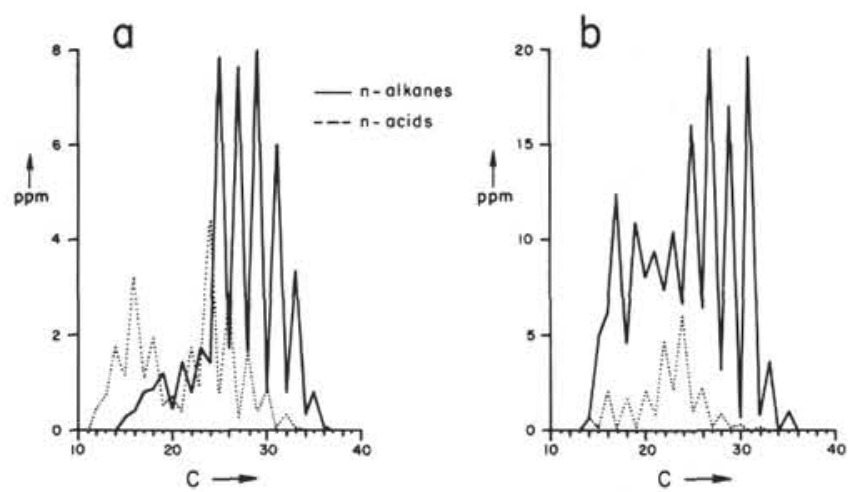

Figure 9. Alkane and acid distribution histograms for the Leg 10 samples (a) Sample 10-90-7-2 (concentrations in approximate ppm of dry sample); (b) Sample 10-92-5-4. one-third that from the Pleistocene sample, although the organic carbon values are approximately the same for both. This indicates that diagenetic processes are operative, polymerizing and incorporating soluble organic matter into "kerogenic" matter.

Organic contamination in these samples was minor. The contaminants which were identified consisted mainly of butyl esters from the core tubes (Simoneit et al., 1972) and phthalate esters.

\section{ACKNOWLEDGMENTS}

We thank Mrs. Amelia Sadorra for technical assistance and Mr. Cary Wong for data reduction. The financial support from the Oceanography Section of the National Science Foundation (NSF Grant GA-24214) is gratefully acknowledged.

\section{REFERENCES}

Simoneit, B.R., in press. Organic Analyses of Black Sea Cores. In Geochemistry and Geophysics of the Black Sea, E.T. Degens and D.A. Ross (Eds.) Mem. Am. Assoc. Petrol. Geologists.

Simoneit, B.R. and Burlingame, A.L., 1971a. Some Preliminary Results on the Higher Weight Hydrocarbons and Fatty Acids in the Deep Sea Drilling Project Cores, Legs 5-7. In Winterer, E.L., Riedel, W.R. et al., 1971. Initial Reports of the Deep Sea Drilling Project, Volume VII. Washington (U.S. Government Printing Office), 889.

1971b. Further Preliminary Results on the Higher Weight Hydrocarbons and Fatty Acids in the Deep Sea Drilling Project Cores, Legs 5-8. In Tracey, J.I. Jr., Sutton, G.H. et al., 1971. Initial Reports of the Deep Sea Drilling Project, Volume VIII. Washington (U.S. Government Printing Office), 873 .

1972a. Further Preliminary Results on the Higher Weight Hydrocarbons and Fatty Acids in the Deep Sea Drilling Project Cores, Leg 9. In Hays, J.D. et al., 1972. Initial Reports of the Deep Sea Drilling Project, Volume IX. Washington (U.S. Government Printing Office), 859.

1972b. Preliminary Analyses of the DSDP (JOIDES)

Cores, Legs V-IX. In Advances in Organic Geochemistry 1971, H. Wehner and H.R. von Gaertner. Oxford-Braunschweig (Pergamon Press), 189.

Simoneit, B.R., Scott, E.W., Howells, W.G. and Burlingame, A.L., 1972. Preliminary Organic Analyses of the Deep Sea Drilling Project Cores, Leg 11. In Ewing, J.I., Hollister, C.D., et al., 1972. Initial Reports of the Deep Sea Drilling Project, Volume XI. Washington (U.S. Government Printing Office), 1013.

Smith, D.H., Olsen, R.W., Walls, F.C. and Burlingame, A.L., 1971. Real-Time Mass Spectrometry: LOGOS-A Generalized Mass Spectrometry Computer System for High and Low Resolution, Gas Chromatography/Mass Spectrometry, and Closed-Loop Applications. Anal. Chem. 43, 1796. 